
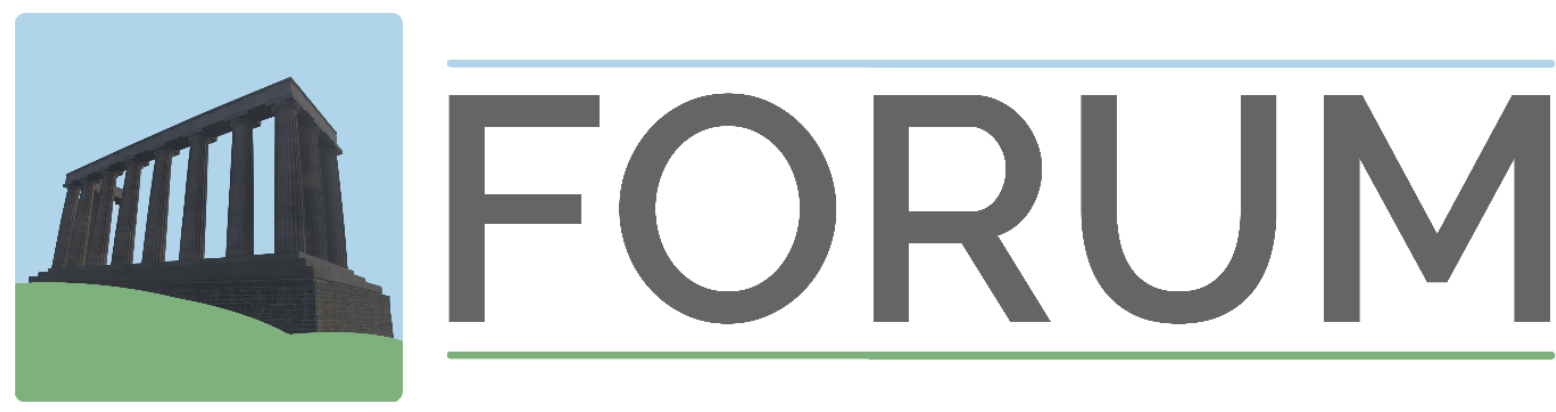

University of Edinburgh

Postgraduate Journal of Culture and the Arts

Issue 32 | Autumn 2021

Title

"I always place my bet on Red": Comrade Detective and the Spectre of Communism

Author

Debayudh Chatterjee

Publication

FORUM: University of Edinburgh Postgraduate Journal of Culture \& the Arts

Issue Number 32

Issue Date

Autumn 2021

Publication Date

$01^{\text {st }}$ October 2021

Editor

Rebeka Luzaityte

FORUM claims non-exclusive rights to reproduce this article electronically (in full or in part) and to publish this work in any such media current or later developed. The author retains all rights, including the right to be identified as the author wherever and whenever this article is published, and the right to use all or part of the article and abstracts, with or without revision or modification in compilations or other publications. Any latter publication shall recognise FORUM as the original publisher. 


\section{"I always place my bet on Red": Comrade Detective and the Spectre of Communism}

\section{Debayudh Chatterjee}

University of Illinois at Urbana-Champaign

The paper analyses the buddy cop TV show Comrade Detective in the light of Jacques Derrida's Spectres of Marx (1994) to demonstrate how it launches a satiric critique of the American state and diplomatic machinery in the aftermath of the fall of the Second Bloc. I argue that this visual text, released in 2017, addresses three contemporary global concernsthe dominance of the USA in a unipolar world, the neoliberal celebration of consumerism, and finally, the rise of right-wing religious fanaticism - through a satiric recreation of the bygone regime of communist Romania of the 1980s.

\section{Introduction}

The 2017 Amazon original Comrade Detective directed by Rhys Thomas masquerades as a lost Romanian TV show of the 1980s remastered and dubbed in English for contemporary audiences. In the prologue, the executive producer Channing Tatum and the writer John Ronson claim that it was created by the then socialist state of Romania to perpetuate communist ideals, anti-capitalist anti-American propaganda, and counter demonised representations of the East Bloc in American productions such as Red Dawn (1984), Rambo III (1988), or Rocky IV (1985). Tagging the show as a "footnote in the dustbin of communist history", they go on to narrate their arduous journey across years and continents to resurrect the show from the archives and present it to the Western world ("1" 00:14-00:29). In truth, it was shot in Romania in 2016 and the characters were played by contemporary Romanian actors. What presentist concerns propel the American cultural industry to relive and recreate memories of an erstwhile communist state almost three decades after its decline? Does it align with the spectrality of Marx that Jacques Derrida reflects on? To address these, it would be important to recall the plot of the show.

Comrade Detective features the story of buddy cop, Gregor Anghel (Florin Piersic Jr), fighting crime and American propaganda on the streets of Bucharest. The action begins when his partner Nikita Ionescu (Cristian Popa) is assassinated by a mysterious killer wearing a Ronald Reagan mask during a drug raid. He is then joined by another detective, Joseph, or 
Iosef Baciu (Corneliu Ulici), a textbook communist, to hunt down the murderer. Their adventure takes them to different places: the American embassy, seedy casinos patronised by the embassy to promote illegal gambling, underground churches that secretly import copies of the Bible to convert Romanians to Christianity, and the luxurious dens of smugglers who bring in Pepsi, the board game Monopoly, rock music, and Jordache jeans, among other banned items to indoctrinate the masses to capitalism. After a twist and turn of events, it is revealed that Nikita faked his death with the aid of his colleague and co-conspirator Stan (Ion Grosu), a corrupt officer in Bucharest PD and a secret American agent. Their motive was to lead the comrades astray, and more importantly, to incite a counter-revolution plotted by the American embassy to overthrow the communist government and establish a globalised, consumerist order imitating the visual decadence of New York City. The show operates on a Western liberalism and East Bloc socialism dialectic finally culminating in the triumph of the latter.

Critical responses to the show have focused predominantly on the element of satire. Sophia Lee of The World magazine points out how "Comrade Detective skewers both communism and capitalism on a kebab stick, roasting them nice and hot over a fire of parody" (19). James Poniewozik of the New York Times focuses on the aspects of Cold War revivalism of the show, dismissing the comic elements of the show. The heavy investment in nostalgia, in his view, makes the show drag. He concludes that Western culture has the power to transform anything into bingeworthy fodder, be it the history of America or any other country, signalling the triumph of neoliberal democracy $(\mathrm{C} 1-\mathrm{C} 11)$. Bill Keveney's pre-release coverage in USA Today also highlights the relevance of the show for how it satirises the Cold War era (1). Nick Gillespie writes, “The genius of the show is that it doesn't simply mock ridiculous communist boasts but forces American viewers to think about the ways in which unexamined jingoism and exceptionalism can seep into the artistic offerings of even a free people" (76). Ironically, Gillespie is reminded of the dangers of jingoism and stereotypical representations of communities only when white, privileged Americans are placed in the receiving end of satire. Only one intervention, an article by Oana Popescu-Sandu, refers to the importance of Comrade Detective in the current political climate, although the focus of her essay is more the elements of dubbing and framing in the show. Popescu-Sandu comments, "it also speaks to contemporary times, when the ideological separation still exists but it is much more porous and uncertain, leading to nostalgia for the imaginary ideological certainty of the bygone era" (420).

This enormous attention to nostalgia in Comrade Detective by film-reviewers and scholars alike aligns with Francis Fukuyama's conclusion in his seminal essay, "The End of 
History?". Shortly before the fall of the Berlin wall, Fukuyama notoriously pronounced the "end of history", arguing that the triumph of Western liberal democracy marks the conclusion of humankind's ideological evolution (3-4). Identifying the communist state, among other twentieth century remnants of absolutism, as an alternative to Western liberalism that has thoroughly exhausted itself, Fukuyama greeted the "post-historical" new order where ideology would be replaced by economic opportunism; there would neither be philosophy, nor art, but "the perpetual caretaking of the museum of human history" as he went on to predict that the nostalgia of the time when history existed would subsequently haunt the world and fuel conflict (18). In response to Fukuyama's infamous pronouncement, Jacques Derrida configured a theory of hauntology in his 1994 book, Spectres of Marx, originally a series of lectures delivered at the University of California Irvine. Derrida posited that the multiple spectres of Marx would continue to haunt this new order from time to time. In my paper, I argue that the recreation of the ideologies of a communist state in the aftermath of the fall of the Second Bloc could be read as such a spectre that haunts the neoliberal world order not just as a critique, but also as a piece of active cultural resistance to the socio-political and economic turbulence that governments and communities across the world have been facing with the ascendance of the fanatic right.

\section{Return of the Spectre in 2017}

Jacques Derrida begins his Spectres of Marx by evoking the spectre of Hamlet's murdered father. In Act I, Scene V, the spectre appears to insinuate Hamlet to avenge his death. Hamlet swears to "set it right" as the "time is out of joint". The metaphor of spectrality could be traced back to Karl Marx and Friedrich Engel's seminal 1848 text, The Communist Manifesto. They begin with the prophesy, "A spectre is haunting Europe-the spectre of Communism" $(2018 ; 20)$. What role does spectrality play in propelling the course of human history even before the communist revolution happened and also after what Fukuyama claimed to be the end of history? The spectre is not exactly a ghost, nor is it a synonym for spirit. Derrida carefully points out the specificity of a spectre; it is not a spirit that assumes a different form, but a "thing that remains difficult to name; neither soul, nor body and both one and the other" (5). Colin Davis argues that "Derrida's spectre is a deconstructive figure hovering between life and death, presence and absence, and making established certainties vacillate" (376). Furthermore, "phantoms lie about the past whilst spectres gesture towards a still unformulated 
future" (379). The liminality of the spirit as it exists between the speculative and the impossible, between idea and reality, connects the past with the present and destabilises axioms of historical exactitude. Just as the spectre of communism that Marx and Engels envisaged in 1848 went on to affect historical events for centuries to come, the spectres of Marx that Derrida observes arising out of the demolition of the Eastern bloc will haunt the subsequent regime of liberal democracy. The communist demands of social equity and redistribution of wealth would become more prominent because the neoliberal order, lacking considerable state intervention, but ruled by multinational corporations operating to maximise profit and exploit labour would inevitably widen the gap between the haves and have-nots. Therefore, basic human needs must be attended for the new order of liberal democracy to flourish. Borrowing the tone of an activist, Derrida writes:

Instead of singing the advent of the ideal of liberal democracy and of the capitalist market in the euphoria of the end of history, instead of celebrating the "end of ideologies" and the end of the great emancipatory discourses, let us never neglect this obvious macroscopic fact, made up of innumerable singular sites of suffering: no degree of progress allows one to ignore that never before, in absolute figures, never have so many men, women, and children been subjugated, starved, or exterminated on the earth. (108)

Derrida argues that the "end of history" by no means stands for the end of ideology, the end of theory, or for that matter, the end of philosophy (16). If it at all stands for anything significant other than amazing, catchy, and almost slogan-like rhetoric, it is merely the end of a certain concept of history that ended much before Fukuyama thought it did. The spectre of Marx cannot easily be exorcised. It would haunt the precarity of the new order whenever human rights are violated, whenever a financial disbalance occurs. Similar to how Hamlet begins with the visit of Hamlet's father's ghost to set things right, Derrida states, "after the end of history, the spirit comes by coming back" (10). As opposed to its near homonym "ontology", hauntology, celebrates the presence of an absence that is beyond life and death and challenges the conjuration of ontology (202).

The hauntological appeal of Comrade Detective is evident in its release date: 2017, within a decade of the 2008 financial crisis that exposed the fault lines of the American capitalist system. In the same year, shortly after Donald Trump's claim to presidency and with the consolidation of sectarian right-wing governments in different parts across the globe, 
Michael Hardt and Antonio Negri wrote a piece in the New Left Review to look back into some of the arguments they made in their 2000 text Empire. In that piece, they observed that while back in 2000, globalisation was being hailed and lauded, one and a half decades later a moment had arrived to conduct its post-mortem. With the death of Pax Americana and the demolition of the new international order that came into being after the fall of the Second Bloc, there has been a rise of reactionary nationalist forces, "undermining trade pacts and presaging trade wars, denouncing supranational institutions and cosmopolitan elites, while stoking the flames of racism and violence against migrants" (67). Even those on the left, in their opinion, unfortunately, subscribe to some of these views as they believe those to be capable of combating neoliberal predations. In this regard, Hardt and Negri argued that globalisation was neither dead, nor in decline, but rendered more obscure, less intelligible. Despite the crisis, global structures have continued to dominate economics and society, which in turn has fomented more crises (67-69). The second half of the second decade of the twenty-first century demonstrates that the precarity of the new order that Fukuyama and his likes greeted with open arms has aggravated; no fundamental qualitative change has been carried out to attend to basic human needs. On the other hand, the rise of the fanatic, extremist forces to power have added more fuel to fire.

\section{Critique of American Capitalism, Imperialism, and Religion in Comrade Detective}

In Spectres of Marx, Derrida brings into consideration the relationship between spectrality and the simulacrum. He argues that spectral logic governs the effects of virtuality, of simulacrum. The spectre, which is neither present, nor absent, but present through an absence, in Derrida's view, is a simulacrum, a set of "synthetic images" subject to multiple readings and interpretations (94). This highlights the cinematic element of the spectre; in fact, it could well include visual texts as plausible mediums for the spectre to communicate. Consequently, attempts to look for realism in Comrade Detective are fruitless; we must not ask how accurately the socialist era in Romania has been represented in the show, but take it as what it stands for: a 2017 American production camouflaging as lost series from Romania of the 1980s, "exhumed" to confront the social, political, and cultural dispensations of its time.

While the show does contain elements of nostalgia, it is ideologically different than other productions of the American culture industry dealing with Cold War revivalism, such as 
The Atomic Blonde (2017) or GLOW (2017-19). In most of these productions, the East Bloc is portrayed as the heavily stereotyped rival other. In contrast to these, Comrade Detective does not resurrect history to sing the glory of the star-spangled banner, but to critique the American state apparatus in its plans to subjugate weaker nations. Cultural productions that dwell solely in nostalgia recall memories of the East Bloc to assassinate it once again and reaffirm the immortality of the American dream. Comrade Detective, on the other hand, foregrounds the East Bloc, listens to the spectre, and tears the American dream apart.

The aspect of spectrality in Comrade Detective is heightened by the mise en scene presence of chess, a symbol of uninterrupted Soviet intellectual domination. Inspired by Bobby Fischer's victory against Boris Spassky in the 1972 world championship, several American televisual texts, such as Pawn Sacrifice (2014), The Coldest Game (2019), and more recently, The Queens Gambit (2020), have deployed this game as a metaphor of the Cold War that predictably ends with the triumph of the lone American warrior over the regimented, manipulative Soviet chess machine. But, unlike the aforementioned American chess movies, in Comrade Detective, chess is not a battleground to determine the intellectual superiority of nations and ideologies, but a common man's rational, everyday exercise. In contrast to Americans in the show glued to football, the detectives, Anghel and Baciu take a keen interest in the game, predict moves, detect blunders, and contemplate about the result of the game. Chess also serves as a foil to the board game Monopoly, another recurring motif in Comrade Detective. In the second episode, the detectives uncover a Monopoly set carefully hidden in a smuggler's car. They learn from two incarcerated elderly subversives (who happened to be Gregor's parents; he turned them in when he found out that they were secretly working for Americans) that Monopoly was designed after the Great Depression of 1929 to reinstate popular faith in capitalism, to indoctrinate children into the market economy. After finding out the rules of the game, Joseph exclaims, "You're telling me that the purpose of this game is to drive your fellow citizens into poverty so you may get rich? It's diabolical!" (10:38-10:55). In subsequent episodes, it is shown that American henchmen are playing Monopoly before their deals.

It is worthwhile to note that a TV show about communist propaganda stars members of the police department as its lead protagonists. The police function as a reliable institution to perpetuate the ideology of the state, thereby casting its hegemonical influence on the people. The first sequence begins with a monologue by Gregor, "You don't become a good communist by going to meetings or memorizing the manifesto. You do it on the streets. You do it with 
your fists. The rest is bullshit. And you know it" (1:31-1:51). So, if, according to Derrida, the academy is responsible for acting as the medium that the spectres of Marx would use to articulate, then these articulations must be translated into praxis by the cadres, organisations, and institutions subscribing to Marxist ideology. Rather than privileging the domination of the academy to preside on matters about Marxism, Comrade Detective places its bet on two cadres enlisted by the state to implement its principles on the streets by physically resisting whatever that could be called its anti-thesis.

The action starts off with Gregor and Nikita busting a couple of "capitalist punks" for peddling cocaine in the underbellies of Bucharest. "You're bringing drugs into this country", Gregor lashes out at them, "so that you can turn our brothers and sisters into addicts?" "The CIA imports drugs so that they can destroy their black communities", Gregor continues, "but at least they have a sick reasoning. What's your dumb ass excuse?" When the accused replies that he did it for money, Gregor asks why they would need money when all their expenses, from education to healthcare, have been paid for by the state ("1"; 06:31-06:58). The question is not whether the CIA imports cocaine here; but the contrast in representing the politics of dissemination of drugs. In TV shows such as Narcos (2015-17), we observe the American cinematic apparatus constructing a Latin American other that produces and transports drugs into the USA. American drug enforcement agents are shown to combat these operations by risking their lives. In shows that deal with stopping the circulation of drugs within the US, such as Breaking Bad (2008-13) or Better or Saul (2015-), we often encounter a monstrous Latin American mastermind like Gus Fring or the Salamanca family responsible for the crimes. All of these narratives push towards contributing to the notion of white American superiority over other races and territories. Comrade Detective strikes hard at the base of this myth by otherising America from the perspective of what America otherises.

In the chapter, Wears and Tears in Spectres of Marx, Derrida observes the alarming growth of "suffer-efficient and properly capitalist phantom-states that are mafia and drug cartels on every continent" that have "infiltrated and banalized themselves everywhere, to the point that they can no longer be strictly identified. Nor even sometimes clearly dissociated from the processes of democratization" (103). He classifies this as one of the ten plagues that would infect the world after the fall of the Second Bloc. In this regard, Comrade Detective visualises a time and space that predates the fall and demonstrates how the rise of such capitalist phantomstates can only be resisted by a strong pro-people ideology like communism. In turn, it also exposes the implicit participation of wealthy nation states, such as the United States, that 
impose a biopolitical regime premised on drugs to govern, control, and marginalise the other within and beyond national boundaries. After Nikita stages his assassination, Gregor is joined by Nikita's childhood friend, Joseph Baciu, another detective. Joseph's visual depiction is strikingly similar to another Joseph: Stalin. With the thick moustache and black hair parted on the left, also the firm iron hand, with which he resolves conflicts, Joseph Baciu alludes to Stalin, under whose leadership after the Second World War, the Soviets emerged as a formidable global adversary to the USA.

This aspect of confrontation is enhanced in the American embassy scene. In a noteworthy frame, we see Gregor and Joseph waiting on a sofa. On a coffee table in front of them are laid copies of "Guns and Ammo" magazines and a bowl of Tootsie rolls. Behind the sofa, is a huge mirror that reflects a photograph of the then president Ronald Regan (12:2212:40). One could infer multiple meanings beyond the literal. Does it allude to the omnipresent surveillance of the Big Brother? Or does the alternative political system of Romania epitomised by Gregor and Joseph hold a mirror in which America can see its face, a reflection of what it really is? It would be useful to recall the immediately preceding dialogues to contextualise what the shot stands for. As the receptionist asks them to wait, she says "the American ambassador is very busy spreading freedom and democracy". "More like spreading greed and gonorrhoea", Gregor snaps back. This unleashes the two points of critique that would run through the series. If the former is unbridled consumerism through which capitalist enterprises operate to maximise their profit, then the latter is how capitalism exoticises, fetishises, and sexualises every object, even human beings, to accelerate the machinations of the former.

Gregor and Joseph interpret capitalism as a form of prostitution throughout the series. Not discounting the gender insensitivity embodied in this metaphor, what the detectives want to reinstate is how capitalism divorces the labourer from their labour, or, how every human act can be reduced to a monetary transaction. In the third episode, as Joseph catches his adolescent daughter in flagrante secretly listening to sexually-charged American pub music on the radio, he explains to her how the transmission of such music is propaganda aimed to indoctrinate Romanian children to the ideals of the free world, how it attempts to "make of all of us prostitutes" (25:21-25:40). In another scene, while telling Gregor about one of his subversive uncles who fled to America and opened a chain of car washes, Joseph does not miss a chance to critique capitalism: “Americans are so lazy that they can't wash their own cars. So, they exploit poor people to do it for them." As he goes on to narrate how his uncle's marriage fell apart and his children took to drugs, he sighs, "How can a man become a father or a husband 
when he only thinks about work and money?" (“2”: 14:20-14:55). Comrade Detective launches a scathing critique of drug use and multiple marriages - extremely common occurrences in everyday American life - by foregrounding the emotional vacuum and existential crisis that accompanies it. Acting as a foil to it, in the next scene, we encounter Joseph's close-knit family, his loving wife and two children when Gregor is invited over to their place for dinner. In contrast to the isolation and emotional deprivation of American life, Comrade Detective paints a picture of a Romanian community where everyone stands by and looks out for one another; where transactions are carried out by fraternal bonds rather than monetary gain.

Joseph also recounts that, as teenagers, he and Nikita went to the United States for three days to participate in a wrestling tournament. While he is still haunted in his nightmares by the poverty, drug scene, prostitution, gang wars, racial marginalisation, and violence lurking under the decadent fabric of New York City, Nikita was seduced by the glitter and glamour of the western world. In the fourth episode, Joseph's wife asks Gregor to find out more about the West. Gregor's interpretation of the United States of America is worth quoting:

The United States was founded in 1776 by a bunch of rich, greedy, white men who didn't want to pay their taxes. For these people, money is the only thing that matters [...] The United States grows it's profiting off slavery, off the working poor, off immigrants. [...] How do they justify this? One word. God. They justify every awful thing they do with the word of God, which brings us to our missing friend, Father Streza, who's been contaminating minds by spreading religion in his underground church, handing out Bibles like candy. Afterall, what poison is more toxic than organized religion? Last but not the least, we have the killer himself. Disguised as Ronald Reagan. Now, who is Ronald Reagan? Ronald Reagan is an actor, a celebrity. The third step of indoctrination is propaganda through popular culture. ("4"; 10:0012:00)

This sarcastic tirade performs quite a few crucial functions in the text. While, on the one hand, it lays bare the essential history of the United States as it stands on years of racial exploitation and victimisation of indigenous tribes, on the other hand, it reminds us of the role religion plays in consolidating these capitalist, imperialist ventures. This is particularly relevant to the context of 2017 as we have seen the rise of white supremacy in the USA, as well as how several other governments in different parts of the globe, such as India, have strengthened themselves through a thorough use of extremist religious rhetoric. In Episode 3, the claim of exercising one's "fundamental right of practicing religion" is greeted with a prompt rebuttal: 
"healthcare is a fundamental right. Believing in an imaginary God is a sign of insanity" (18:4619:12). Joseph and Gregor discussion on the mass belief in superpower aligns with Karl Marx's famous claim: "Religion is the sigh of the oppressed creature, the heart of a heartless world, and the soul of soulless conditions. It is the opium of the masses" $(1970 ; 131)$. At a moment when it has become impossible to disassociate culture from religion with inter-religious wars fomenting to hideous extents in Palestine, or India, or Myanmar, the detectives remind us of the long forgotten, intrinsic values of the Enlightenment: the need to think for one's self and question all the existing pillars of the society, including religion. Later on, in the same episode, Jane, the receptionist at the American embassy, confesses, "Some of us in the west don't actually believe in religion. We just pretend to convince a bunch of half-wits to vote for us" (28:24-28:31).

\section{Conclusion}

In the final episode, after it has been unravelled that Nikita and Stan were conspiring to overthrow the Romanian government, in a dramatic turn of events, Gregor's life is saved from a dagger aimed at his heart by a Karl Marx book that he keeps in the pocket of his overcoat. Soon after, Gregor dismembers both of Nikita's hands after hearing him laud the invisible hand of the market, literally rendering his hands invisible. Through the devices of satire, comedy, and parody, Comrade Detective animates a series of tongue-in-cheek communist jibes at the immanent problems that owe their roots to the free market economy. It would, however, be a mistake to assume that the show serves as a vehicle to revive communist propaganda after the collapse of the new order. What it does, by thematically encapsulating the parody of a bygone regime is expose the heinous machinations of the American state apparatus. To do so, it incorporates the spectres within and beyond its literal contours. Let us end by mentioning a topical reference, in which the show takes an indirect jab at the forty fifth president of America, who inadvertently finds an overwhelming presence of communists, anarchists, rioters, and terrorists at any major protest. In the penultimate episode, a conversation between the undercover American agent Stan and his loyal communist colleague Dragos is worth quoting.

- I heard about this American. He builds skyscrapers in New York City, and he puts his name in gold letters on every building he erects, imagine that!

- Sounds like an asshole. 
- And what's wrong with that?

- Because it takes many men to erect a building, not just one. Everyone contributes to the most of their ability. [27:99-28.30]

And this is how Comrade Detective reminds us of the exigence to champion the rights and demands of the impoverished majority over the privileged, affluent few, provoking us to participate in a project of reimagining and redefining the left. 


\section{Works Cited}

Anderson, John. “'Comrade Detective' Review: Cold War Nostalgia with a Fictional Twist; Amazon 'Rediscovers"” a Romanian Government-Produced Police Drama that Never was." Wall Street Journal (Online), Aug 03, 2017.

Bill Keveney. "Two 'Comrade's Give Voice to Quirky Show.” Dayton Daily News (Ohio), Aug 5, 2017.

Comrade Detective. Directed by Rhys Thomas, Season 1, Amazon Prime Video, 2017

Davis, Colin. "Hauntology, Spectres and Phantoms." French Studies: A Quarterly Review, Vol. 59, No. 3, July 2005, pp. 373-379.

Derrida, Jacques. Spectres of Marx : the State of the Debt, the Work of Mourning, and the New International. Routledge, 1994.

Fukuyama, Francis. “The End of History?” The National Interest, No. 16, 1989, pp. 3-18.

Gillespie, Nick. “Comrade Detective.” Reason, Vol. 49, No. 6, Nov. 2017, p. 76.

Hardt, Michael, and Antonio Negri. "Empire, Twenty Years On.” New Left Review, No. 120, Nov. 2019, pp. 67-94.

Lee, Sophia. “Comrade Detective.” World, Vol. 32, No. 16, Sept. 2017, p. 19.

Marx, Karl. Communist Manifesto: with an Introduction by Yanis Varoufakis. Vintage Classics, 2018. . Critique of Hegel's “Philosophy of Right”. Cambridge University Press, 1970.

Poniewozik, James. “Nostalgia Goes Niche.” New York Times, Vol. 166, No. 57679, 4 Aug. 2017, pp. C1-C11.

Popescu-Sandu, Oana. “'What Would Lenin Do?': Multidirectional Cold War Nostalgia in Comrade Detective." Slavic \& East European Journal, Vol. 64, No. 3, Fall 2020, pp. $420-434$. 


\section{Author Biography}

Debayudh Chatterjee is a PhD student at the Department of English, University of Illinois at Urbana-Champaign. His research interests include Marxism, progressive politics in South Asia, avant-garde literatures, and global modernisms. He also translates extensively from Bengali into English and vice-versa. 